Witold Jarno

Uniwersytet Łódzki

iD ORCID: 0000-0002-5845-6057
OBLICZA WOJNY

TOM 4 - MIASTO I WOJNA

ŁÓDŹ2021 • ISBN 978-83-8220-617-3•s. 233-264

https://doi.org/10.18778/8220-617-3.13

\title{
BITWA O MSZCZONÓW WE WRZEŚNIU 1939 ROKU
}

\begin{abstract}
Streszczenie. W artykule opisano zdobycie Mszczonowa przez żołnierzy 31 Pułku Strzelców Kaniowskich w dniu 11 września 1939 r. Pułk w tym czasie walczył w oderwaniu od własnej 10 Dywizji Piechoty i samodzielnie cofał się ku Wiśle. Bój, stoczony przez pułk, był jednym z największych sukcesów jego żołnierzy w trakcie kampanii wrześniowej w 1939 r., choć przez wiele lat pozostawał w cieniu toczonej równolegle bitwy nad Bzurą. Dopiero w ostatnim czasie zaczęto przywracać pamięć o tym - nieco zapomnianym - zwycięstwie. Zdobycie Mszczonowa przez oddziały 31 Pułku Strzelców Kaniowskich przyniosło mu wojenną chwałę. Swoim działaniem doprowadził, choć na krótko, do powstania zamieszania w dowództwie niemieckiego XVI Korpusu Armijnego, które nie orientowało się w siłach, jakie wzięły udział w walce. Żołnierze ppłk. Wincentego Wnuka odnieśli sukces taktyczny, który - choć nie przyniósł korzyści operacyjnych - podniósł jednak upadające morale. Należy podkreślić, iż za to zwycięstwo pułk został odznaczony w 1966 r. orderem Virtuti Militari V klasy.
\end{abstract}

Słowa kluczowe: wojna polsko-niemiecka w 1939 r., Mszczonów, podpułkownik Wincenty Wnuk, 31 Pułk Piechoty

Tematem artykułu są walki stoczone przez 31 pSK ${ }^{1}$ dowodzony przez ppłk. Wincentego Wnuka² o Mszczonów rankiem 11 września 1939 r. Choć nie miały one wymiaru operacyjnego, a jedynie taktyczny, to jednak wprowadziły

${ }^{1}$ W niniejszym artykule użyto następujących skrótów: CAW WBH - Centralne Archiwum Wojskowe, Wojskowe Biuro Historyczne; DP - Dywizja Piechoty; DPanc. - Dywizja Pancerna; pal - pułk artylerii lekkiej; pSK - Pułk Strzelców Kaniowskich; ZKRPWP - Związek Kombatantów Rzeczypospolitej Polskiej i byłych Więźniów Politycznych Zarząd Okręgowy w Łodzi.

2 Szerzej o ppłk. Wincentym Wnuku. Vide: CAW WBH, ap. Wincenty Wnuk, sygn. 4849, Karta kwalifikacyjna dla Komisji Weryfikacyjnej z 1921 r., karty bez paginacji; CAW WBH, ap. Wincenty Wnuk, Teczka Akt Personalnych, sygn. 742.61.2048, Zeszyt ewidencyjny, k. 6; W. KoZŁOWSKI, Ptk Wincenty Wnuk (1897-1987), żotnierz i dowódca września 1939 r. Szkic biograficzny, 
duże zamieszanie w działaniach wojsk niemieckich, pokazując zarazem wolę walki i determinację polskiego żołnierza. Bój ten był jednym z większych sukcesów żołnierzy 31 pSK w trakcie kampanii wrześniowej, choć przez wiele lat pozostawał w cieniu toczonej równolegle bitwy nad Bzurą. Dopiero w ostatnim okresie zaczęto wracać do tego nieco zapomnianego i często niedocenianego zwycięstwa. Wyrazem uhonorowania wysiłku i poświęcenia żołnierzy 31 pSK stała się wizyta Prezydenta Rzeczypospolitej Polskiej Lecha Kaczyńskiego w Mszczonowie w dniu 11 września 2007 r. Było to wielkie wydarzenie dla współczesnych mieszkańców miasta, w którym nigdy dotąd nie gościła oficjalnie Głowa Państwa. Wówczas też - z udziałem Prezydenta - zorganizowano po raz pierwszy uroczystości rocznicowe bitwy mszczonowskiej, które stały się odtąd jednym z najważniejszych symboli tradycji historycznej Mszczonowa ${ }^{3}$.

Bój 31 pSK o wspomniane miasto stoczony 11 września 1939 r. był dla jego żołnierzy zaledwie jednym z etapów długiej epopei wojennej, lecz przyniósł im nieśmiertelną chwałę, przyczyniając się zarazem dla podtrzymania upadającego morale. Pułk do tego czasu walczył w składzie 10 DP dowodzonej przez gen. bryg. Franciszka Dindorfa-Ankowicza (ponadto 28 i 30 pSK oraz 10 pal) i wraz z nią przez pierwsze dni kampanii wrześniowej bronił głównej pozycji obronnej Armii „Łódź” (dowodzonej przez gen. dyw. Juliusza Rómmla) opartej o rzekę Wartę w rejonie Sieradza. Po jej opuszczeniu dywizja cofała się w kierunku Zgierza i Skierniewic, lecz po drodze uległa częściowemu rozproszeniu. Od 8 września przegrupowania oddziałów 10 DP odbywały się beż żadnej koordynacji, przez co rozeszły się one w różnych kierunkach i prowadziły w praktyce samodzielne działania odwrotowe.

Podobnie było w przypadku 31 pSK, który w południe 8 września opuścił rejon Pszczonowa (18 km na wschód od Głowna) i zgodnie z rozkazem dowódcy 10 DP - skierował się w kierunku Otwocka. Przed zmierzchem dotarł do Skierniewic, skąd następnej nocy przegrupował się o kolejne $20 \mathrm{~km}$ w kierunku wschodnim, docierając rankiem 9 września do Puszczy Mariańskiej (około

[w:] Si vis pacem, para bellum. Bezpieczeństwo i polityka Polski. Ksiegga jubileuszowa ofiarowana profesorowi Tadeuszowi Dubickiemu, red. R. MajZner, Częstochowa-Włocławek 2013, s. 803-822; A. WesoŁowski, Podputkownik Wnuk i jego żotnierze, [w:] Żotnierze Września 1939, red. K. SIKORA, A. WesoŁOWski, Warszawa 2012, s. 326-328.

3 Wrzesień 2007. Wyjątkowy mszczonowski wrzesień, „Merkuriusz Mszczonowski” 2007, nr 8 (130), s. 1-2. 


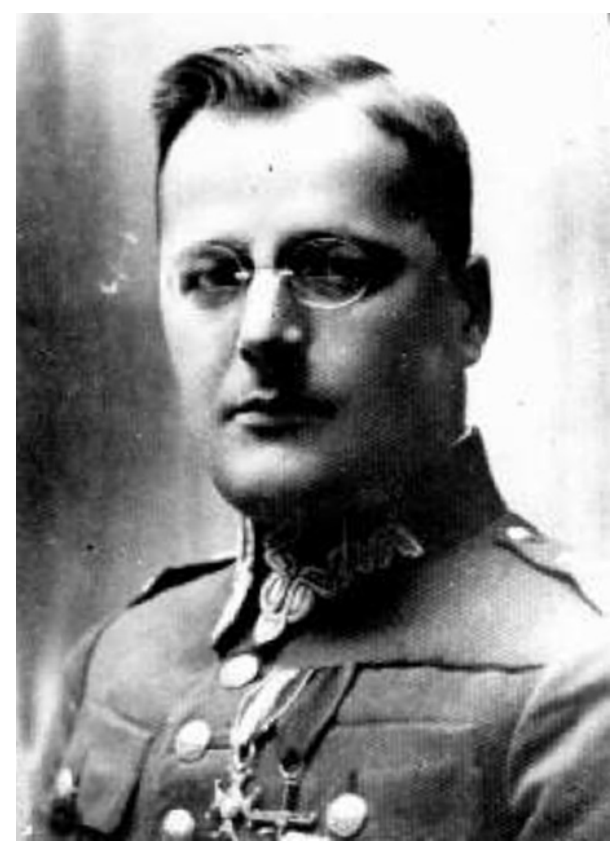

Ryc. 1. Podpułkownik Wincenty Wnuk - dowódca 31 pSK we wrześniu 1939 r.

(źródło: Autor „niedocenianego zwycięstwa”, „Merkuriusz Mszczonowski” 2007, nr 8 (130), s. 26)

20 km na wschód od Skierniewic). Od tej pory jego dowódca ppłk W. Wnuk nie miał już łączności z własną dywizją.

W trakcie odwrotu zatłoczonymi drogami doszło do rozproszenia części pododdziałów 31 pSK, jak np. zasadniczej części II batalionu mjr. Antoniego Zwolińskiego, która odłączyła się od pułku 8 września i kilka dni później dotarła do Wisły na wysokości Otwocka ${ }^{4}$. Natomiast wchodząca w skład tego batalionu 5 kompania strzelecka (dowodzona przez kpt. Feliksa Sitnego) pozostała przy kolumnie głównej 31 pSK i wraz z głównymi siłami pułku znalazła się rankiem 9 września w rejonie Puszczy Mariańskiej. Z uwagi na kilkudniowe działania odwrotowe oraz zmęczenie żołnierzy i przemieszanie się części pododdziałów pułku na zatłoczonych drogach - dzień ten ppłk W. Wnuk przeznaczył na odpoczynek i uporządkowanie szeregów jednostki. Wielu żołnierzy zagubiło się po drodze i dopiero za dnia część z nich zdołała dotrzeć do nowego rejonu

\footnotetext{
${ }^{4}$ Po przeprawie przez Wisłę pododdział ten wszedł w skład odtwarzanej na Lubelszczyźnie $10 \mathrm{DP}$ - jako II batalion $31 \mathrm{pSK}$.
} 
koncentracji pułku. Wielkim problemem - wobec utraty większości taborów - było zapewnienie strudzonym piechurom ciepłej strawy oraz uzupełnienie amunicji, bez której trudno było realnie myśleć o dalszej walce. Na szczęście pobliskimi drogami przemieszczały się liczne wozy taborowe z rozbitych jednostek Armii „Łódź”, co pozwoliło zaopatrzyć się żołnierzom 31 pSK w niezbędną żywność oraz amunicję do broni strzeleckiej. Do pułku włączono wówczas wielu zagubionych żołnierzy z innych jednostek, dzięki czemu stan jednostki pod koniec dnia wzrósł do około tysiąca ludzi, co w praktyce stanowiło równowartość jednego batalionu. Najsilniejszym pododdziałem był I batalion mjr. Bolesława Raczkowskiego liczący niemal 500 żołnierzy, który stanowił teraz główną siłę bojową 31 pSK, najsłabszym zaś - II batalion mający w swym składzie jedynie 5 kompanię strzelecką. Bolączką pułku była słaba artyleria, którą tworzył pułkowy pluton artylerii oraz kilka armat przeciwpancernych. Nic dziwnego, że w tej sytuacji ppłk. W. Wnuka ucieszyło przybycie 10 września - po kilkudniowym współdziałaniu z Kresową Brygadą Kawalerii - III dywizjonu 10 pal, składającego się wówczas z trzech baterii (dwóch własnych - 8 i 9 oraz 3 baterii z I dywizjonu), dowodzonego przez mjr. Michała Borka. Było to dla $31 \mathrm{pSK}$ istotne wzmocnienie ogniowe, które niebawem odegrało ważną rolę w walkach o Mszczonów 5 .

W rejonie Puszczy Mariańskiej 31 pSK przebywał dwa dni (9-10 września). Czas ten przeznaczono na przywrócenie jednostce zdolności do walki, osłabionej przez długi i męczący odwrót znad Warty. Wobec braku łączności z dowództwem własnej dywizji ppłk W. Wnuk usilnie starał się uzyskać informacje o sytuacji w rejonie Skierniewic. Jednak cofający się żołnierze z różnych rozproszonych jednostek niewiele na ten temat wiedzieli, toteż trzeba było zachować ostrożność i prowadzić stałe rozpoznanie, przy jednoczesnym dalszym podejmowaniu prób skontaktowania się z dowództwem macierzystej dywizji.

Dnia 10 września sytuacja 31 pSK zaczęła się pogarszać, gdyż zwiadowcy pułkowi poinformowali ppłk. W. Wnuka, że w oddalonym o kilkanaście kilometrów Mszczonowie zauważono obecność niemieckich pododdziałów ${ }^{6}$. Tego samego dnia dowiedział się on także od napotkanego płk. dypl. Stefana Broniowskiego (dowódcy Piechoty Dywizyjnej 28 DP), że w rejonie Skierniewic

5 J. Wróblewski, Armia „£ódż” 1939, Warszawa 1975, s. 265; P. ZARZyCKi, 10 Kaniowski Putk Artylerii Lekkiej, Pruszków 1997, s. 32-33; P.A. KunuŁA, Maszerują strzelcy, Łódź 1972, s. 172-173.

${ }^{6} \mathrm{~J}$. WRÓBLEWSKI, op. cit., s. 265. 
przebywa gen. bryg. Wiktor Thommée, dowódca Grupy Operacyjnej „Piotrków" (składającej się z pozostałości 28 i 30 DP oraz Wołyńskiej Brygady Kawalerii, a od 7 września także 2 DP Legionów) 7 . Jednak w ogólnym chaosie panującym na drogach, dotarcie do wspomnianego generała - celem uzyskania nowych rozkazów - nie było proste, gdyż niemal cały dzień przebywał on w ruchu i dopiero w godzinach popołudniowych przybył do sztabu 30 DP gen. bryg. Leopolda Cehaka w Karolinowie, oddalonym od Puszczy Mariańskiej o około $10 \mathrm{~km}$ w kierunku zachodnim. Tu gen. bryg. W. Thommée przekazał swój rozkaz do dalszego odwrotu rozproszonych jednostek Armii „Łódź” w kierunku Warszawy, który miał się odbywać m.in. przez Mszczonów.

Miasteczko to odgrywało w tym czasie ważną rolę militarną, gdyż przebiegała przez nie tzw. szosa piotrkowska, czyli główna droga prowadząca z Częstochowy i Piotrkowa Trybunalskiego w kierunku Warszawy, oddalonej o zaledwie $50 \mathrm{~km}$. To właśnie ową szosą przemieszczały się w stronę polskiej stolicy główne siły niemieckiego XVI Korpusu Armijnego (w polskiej historiografii zwanego XVI Korpusem Pancernym) gen. kawalerii Ericha Höpnera (m.in. 1 DPanc. gen. por. Rudolfa Schmidta, 4 DPanc. gen. mjr. Georga-Hansa Reinhardta, 14 DP gen. por. Petera Weyera i 31 DP gen. por. Rudolfa Kämpfego) wchodzącego w skład 10 Armii gen. artylerii Walthera von Reichenaua. Rola Mszczonowa niepomiernie wzrosła 6 września, gdy - po porannym nalocie na sztab Armii „Łódź” - zakwaterowany w pałacu Heinzla w Łodzi, dowodzący nią gen. dyw. J. Rómmel, nakazał pospieszne przeniesienie dowództwa armii w kierunku Warszawy. Nowym miejscem postoju sztabu armii stały się początkowo Brzeziny, lecz zniszczenie tamtejszej centrali telefonicznej spowodowało, iż konieczne stało się znalezienie innego miejsca. Wybór padł na Mszczonów, gdzie kolumna samochodów pierwszego rzutu sztabu (z dowódcą armii) przybyła około godziny 10.00. Pomieszczenia sztabowe ulokowano w budynku poczty w centrum miasteczka oraz w kilku budynkach położonych przy ul. Warszawskiej. Nie była to jednak odpowiednio przygotowana wcześniej kwatera dowodzenia, przez co dowództwo Armii „Łódź” straciło w praktyce możliwość sprawnego dowodzenia podległymi siłami. Udało się uzyskać jedynie łączność telefoniczną z Naczelnym Dowództwem oraz drugim rzutem armii

\footnotetext{
7 Ponieważ gen. dyw. J. Rómmel stracił kontakt z podległymi związkami taktycznymi, rolę dowódcy armii de facto przejął gen. bryg. W. Thommée.
} 
rozlokowanym w Grodzisku i Żyrardowie ${ }^{8}$. Oto jak gen. dyw. J. Rómmel wspominał swój pobyt w Mszczonowie:

Budynek poczty, mały drewniany domek, stał na rozwidleniu dwóch szos, którymi płynął nieprzerwanie potok cofających się taborów, masy uciekinierów i tłumy rozbitków. Z przerażeniem dowiedziałem się od żołnierzy, że były to resztki oddziałów 19 i 13 DP armii „Prusy”, które już rano 6 IX. cofały się przez Mszczonów ku Warszawie?.

Jakby nie dosyć - zaledwie kilka godzin po przybyciu sztabu armii do Mszczonowa - miasteczko stało się celem niemieckich samolotów. Pierwszy nalot po godzinie 13.00 przeprowadziło kilka bombowców He-111 z 2 dywizjonu 26 Pułku Bombowego, po godzinie 16.00 zaś samoloty z 4 Pułku Bombowego ${ }^{10}$. Pierwszy nalot tak zapisał się w pamięci dowódcy Armii „Łódź”: „Wkrótce nadleciały na te tłumy eskadry bombowców i zaczęło się piekło na ziemi. Kilka bomb trafiło w pobliskie domy, powstały pożary, wszędzie leżeli ranni i zabici. Po tych przeżyciach nerwy zaczęły mi odmawiać posłuszeństwa" ${ }^{11}$. Na początku drugiego nalotu sztab armii stracił łączność telefoniczną z Naczelnym Dowództwem. W tej sytuacji gen. dyw. J. Rómmel zdecydował przenieść sztab armii do pobliskiej miejscowości Grzegorzewice, położonej około $10 \mathrm{~km}$ na wschód od Mszczonowa - dokąd kolumna samochodowa udała się (według wspomnień generała) około godziny $20.00^{12}$.

Niemieckie naloty przeprowadzone 6 września spowodowały duże zniszczenia w niewielkim Mszczonowie. Spłonęło około 30 budynków, śmierć poniosło zaś niemal trzydzieści osób, w tym kilku żołnierzy. Przez palące się miasto cały dzień przemieszczały się tłumy uciekinierów oraz rozbite we wcześniejszych walkach polskie oddziały. Podobnie wyglądała sytuacja następnego dnia (7 września) - wtedy również Mszczonów stał się w godzinach rannych celem nalotu niemieckich samolotów (m.in. sztukasów Ju-87B) z 21 Pułku Myśliwskiego

\footnotetext{
${ }^{8}$ J. WróbLEWSKI, op. cit., s. 167-168.

9 J. Rómmel, Za honor i Ojczyznę. Wspomnienia dowódcy armii „Eódz”" i „Warszawa”, Warszawa 1958 , s. 134.

10 M. Emmerling, Luftwaffe nad Polska 1939, cz. 2: Kampfflieger, Gdynia 2005, s. 122 i 133.

${ }^{11}$ J. RómmeL, op. cit., s. 134.

12 Ibidem, s. 138. Podobny opis tego nalotu-vide: Mszczonów (relacjaświadka), „Żołnierz Polski w Kampanii Wrześniowej” 1941, nr 31, s. 2 (dodatek do „Wiadomości Polskich” 1941, nr 31).
} 
i 77 Pułku Lotnictwa Szturmowego ${ }^{13}$. Atak Luftwaffe „trwał dwie i pół godziny. Lotnicy niemieccy czuli się bezkarni. Schodzili na niewielkie wysokości i strzelali do uciekinierów z broni pokładowej. Zginęło wtedy 9 osób cywilnych i dwóch żołnierzy"14. Chaos na drogach w rejonie Mszczonowa był ogromny, czemu nie można się dziwić, gdyż to właśnie tędy prowadziła główna szosa z Rawy Mazowieckiej ku stolicy. Z tej przyczyny miasteczko miało duże znaczenie dla niemieckiego XVI Korpusu Armijnego nacierającego w kierunku Warszawy. Stanowiło ono ważny węzeł drogowy, gdyż - obok wspomnianej szosy - zbiegały się tu także drogi z Sochaczewa, Żyrardowa, Skierniewic i Grójca. Nic dziwnego, że w tej sytuacji Niemcom zależało na jak najszybszym zajęciu Mszczonowa, zwłaszcza w kontekście trwających przegrupowań niemieckich jednostek w związku z trwającą bitwą nad Bzurą.

Pierwsze niemieckie oddziały wkroczyły do miasteczka w godzinach porannych 8 września i przez kolejne trzy dni mieszkańcy byli świadkami przemieszczania się kolejnych jednostek niemieckich, kierujących się w stronę polskiej stolicy. Już pierwszy dzień niemieckich rządów w Mszczonowie pokazał ich bezwzględność, gdyż na placu przy ul. Grójeckiej rozstrzelano dziesięciu polskich jeńców oraz jednego cywila. Z kolei w nocy z 8 na 9 września doszło do przypadkowej strzelaniny kilku żołnierzy niemieckich, w wyniku której jeden z nich zginął. Winą za ten incydent obarczono mieszkańców miasteczka i w odwecie rozstrzelano około dwadzieścia pięć osób oraz spalono kilka kolejnych domów. Następnego dnia (10 września) do Mszczonowa przybyły pododdziały tyłowe XVI Korpusu Armijnego, w tym 1 i 4 DPanc. oraz 31 DP - dysponujące ciągnikami artyleryjskimi, ciężarówkami, czołgami oraz licznymi taborami konnymi. Zostały one rozlokowane m.in. wzdłuż ul. Rawskiej, na placu Piłsudskiego, Nowym Rynku oraz na polu za tzw. starym cmentarzem ${ }^{15}$.

W tym miejscu pora powrócić do 31 pSK przebywającego od 9 września w rejonie Puszczy Mariańskiej, kilkanaście kilometrów na zachód od Mszczonowa. Następnego dnia gen. bryg. W. Thommée przekazał około godziny 16.00 dowódcy 30 DP rozkaz odwrotu przez Mszczonów w kierunku Warszawy.

13 M. Emmerling, Luftwaffe nad Polska 1939, cz. 1: Jagdflieger, Gdynia 2002, s. 100; cz. 3: Stukaflieger, Gdynia 2006, s. 94-95.

14 P. Dymecki, Bitwa mszczonowska 31 Putku Strzelców Kaniowskich, „Merkuriusz Mszczonowski" 2008, nr 9, s. 15.

15 P. Dyмeскi, Mszczonowski wrzesień 1939, https://www.mszczonow.pl/249,mszczonowski-wrzesien-1939?tresc=273 (dostęp: 22 VIII 2020). 
Dowodzący nią gen. bryg. L. Cehak miał z kolei nakazać 31 pSK, który utracił kontakt z macierzystą dywizją, by ten oczekiwał w kolumnie marszowej na czoło przegrupowującej się 30 DP, by wspólnie uderzyć na Mszczonów. Według por. Mieczysława Chrzanowskiego, dowódcy kompanii zwiadu 31 pSK, miała ona nawiązać łączność z gen. bryg. W. Thommée oraz ze sztabem 30 DP, co sugerowałoby, iż dowódca 31 pSK został powiadomiony o planowanym natarciu i podporządkowaniu podległej mu jednostki dowódcy $30 \mathrm{DP}^{16}$. Jednak według ppłk. W. Wnuka - nie dostał on tych rozkazów i działał w kolejnym dniu z własnej inicjatywy. Wydaje się to całkiem realne, gdyż w panującym chaosie i stale przemieszczających się dowództwach jednostek, odnalezienie i przekazanie na czas nowych rozkazów, było niezmiernie trudne, a często wręcz niemożliwe. Jednak według innej informacji ppłk W. Wnuk miał przysłać do gen. bryg. L. Cehaka oficera łącznikowego, celem uzgodnienia współdziałania pułku z dywizją. Wówczas to dowódca $30 \mathrm{DP}$ miał podporządkować sobie 31 pSK i nakazać, by oczekiwał on na oddziały dywizji w miejscowości Rudka Młyn (inne nazwy: Młyn Rudka i Ruda-Osada Młyńska) ${ }^{17}$, skąd miało wyjść wspólne uderzenie na Mszczonów, mające otworzyć dalszą drogę odwrotu w kierunku północno-wschodnim ${ }^{18}$. Z kolei według Włodzimierza Kozłowskiego:

O obecności Niemców w Mszczonowie generał wiedział od żołnierzy-rozbitków, których spotkał na szosie spalskiej; rozbrojeni - jechali wozami taborowymi przez Kamion (na wschód od Skierniewic). Właśnie dlatego gen. bryg. L. Cehak, dowódca $30 \mathrm{DP}$, liczył na współpracę z 31 pSK, spodziewając się trudności podczas opanowania Mszczonowa. Ba, generał czekał w m. Rudka Młyn (Ruda-Osada Młyńska) do godz. 3.00 (11 września) na ten pułk. Gdy go nie było, zaniechał - po uzgodnieniu z gen. bryg. W. Thommée - marszu na Mszczonów i wycofał swoje siły do rejonu Puszczy Mariańskiej. Tam zamierzał przeczekać dzień 11 września, obawiając się słusznie konfrontacji z przeważającymi siłami wroga (niemiecka 31 DP w rejonie Nadarzyn-Piaseczno i - jak teraz wiadomo - elementy 18 lub 19 DP z rejonu Lipie-Wilków-Konopnica) ${ }^{19}$.

16 Polskie Sity Zbrojne w II wojnie światowej (dalej: PSZ), t. 1: Kampania wrześniowa, cz. 3, Przebieg dziatań od 9 do 14 września, Londyn 1959, s. 175; J. WróBlewski, op. cit., s. 267-268; W. Jarno, W. KozŁowski, 10 Dywizja Piechoty w wojnie 1939 roku, Pruszków 2016, s. 228.

${ }^{17}$ J. WróblewsKi, op. cit., s. 268-269; PSZ, t. 1, cz. 3, s. 174 i szkic nr 3.

${ }_{18}$ Ibidem, s. 267-268.

19 W. Jarno, W. KozŁowski, op. cit., s. 228. 
Trudno jednoznacznie rozstrzygnąć - o czym wcześniej zasygnalizowano - czy ppłk W. Wnuk miał łączność z gen. bryg. W. Thommée lub z gen. bryg. L. Cehakiem, a jeżeli tak, to dlaczego 31 pSK nie dotarł o umówionej godzinie w wyznaczone miejsce koncentracji w okolicy miejscowości Rudka Młyn, na południowo-wschodnim skraju Puszczy Mariańskiej ${ }^{20}$. Według dowódcy I batalionu mjr. B. Raczkowskiego - ppłk W. Wnuk otrzymał rozkaz do wspólnego uderzenia na Mszczonów nie z dowództwa 30 DP, lecz bezpośrednio ze sztabu gen. bryg. W. Thommée. Zgodnie z nim 31 pSK miał przegrupować się przez Nową Hutę, Świnice, Mszczonów, Grzegorzewice i Suchodół w kierunku Tarczyna, a więc dwa kilometry dalej na północ, niż określił to dowódca 30 DP. Tym samym - zakładając iż wspomniany rozkaz faktycznie dotarł do sztabu 31 pSK - pułk podjął marsz w kierunku wschodnim kilka godzin wcześniej niż 30 DP i przemieszczał się drogami położonymi nieco bardziej na północ, niż trasa marszu oddziałów podległych gen. bryg. L. Cehakowi. W konsekwencji pułk nie mógł spotkać kolumn marszowych tej dywizji. Powyższe fakty mogą świadczyć o złym przepływie informacji w polskich sztabach, gdyż gen. bryg. W. Thommée i gen. bryg. L. Cehak wydali dwa nieco odmienne rozkazy, które spowodowały zamieszanie w przegrupowaniu polskich jednostek. Oddziały 30 DP rozpoczęły marsz po zmierzchu i po przejściu około dwudziestu kilometrów jej czołowy 82 pp ppłk. dypl. Antoniego Chruściela zatrzymał się w rejonie miejscowości Rudki Młyn, gdzie miał dołączyć 31 pSK. Tego jednak w tej okolicy nie było, gdyż w kierunku Mszczonowa przemieścił się - jak wcześniej podano - drogami biegnącymi kilka kilometrów dalej na północ od miejscowości Rudki Młyn. Pułki 30 DP przebywały w osiągniętym rejonie do godziny 3.00 (11 września), po czym - po analizie ogólnej sytuacji - gen. bryg. L. Cehak odwołał planowane natarcie na Mszczonów i nakazał powrót do Puszczy Mariańskiej, skąd miano przebijać się do stolicy poprzez Żyrardów. Ta decyzja dowódcy 30 DP została tego dnia zatwierdzona przez gen. bryg. W. Thommée. W konsekwencji nie doszło do współdziałania 31 pSK z pułkami 30 DP. Należy tu pamiętać, iż przemęczeni i głodni żołnierze, przy braku map i łączności szybko tracili orientację w zalesionym terenie, co zapewne również mogło być powodem braku wspomnianego współdziałania w nocy z 10 na 11 września ${ }^{21}$.

\footnotetext{
${ }^{20}$ J. WRÓBLEWSKI, op. cit., s. 269.

${ }^{21}$ M. Bielski, Grupa Operacyjna „Piotrków” 1939, Warszawa 1991, s. 220 i 230-231; PSZ, t. 1, cz. 3, s. 175; J. WróbLE WSKI, op. cit., s. 267-269; L. GŁOWACKi, Obrona Warszawy i Modlina na tle
} 


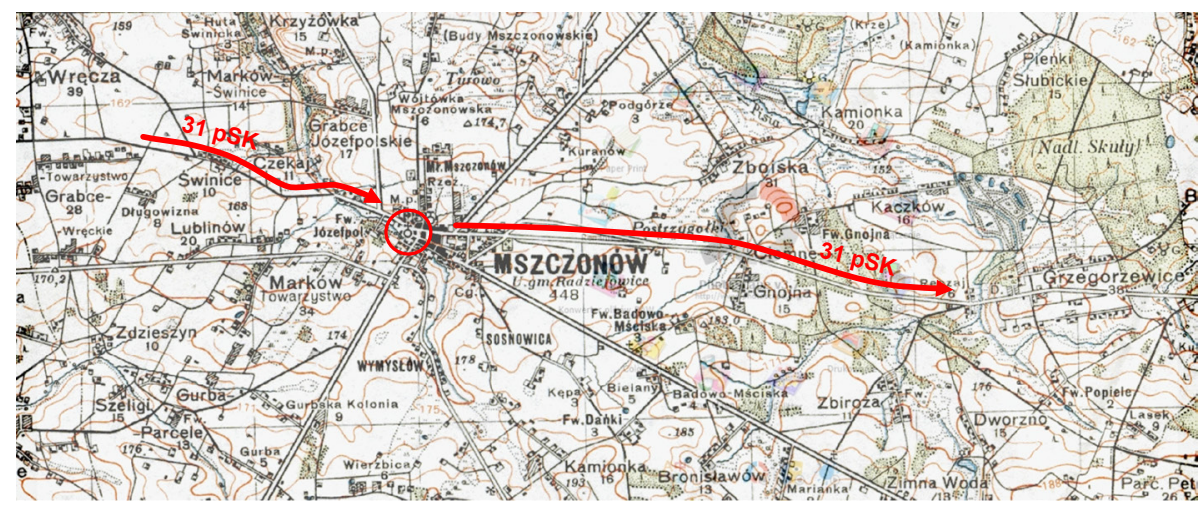

Ryc. 2. Okolice Mszczonowa w 1937 r.

(źródło: Mapa WIG w skali 1:100.000, P41-S31, Warszawa 1937)

Przed świtem 11 września 31 pSK dotarł w okolice Mszczonowa. W straży przedniej szedł I batalion mjr. B. Raczkowskiego - wzmocniony pułkowym plutonem artylerii piechoty ${ }^{22}$ oraz działami 3 baterii 10 pal. Za nimi maszerował III batalion dowodzony przez kpt. Kazimierza Skorupskiego (nominalnego dowódcę 8 kompanii strzeleckiej, który przejął dowodzenie batalionem 6 września po zranieniu mjr. Tadeusza Ujwarego) i pozostała w pułku część II batalionu pod dowództwem kpt. F. Sitnego, za którymi podążał III dywizjon 10 pal mjr. M. Borka, ocalałe tabory pułku oraz niedobitki 30 pal ppłk. Zygmunta Lewandowskiego i 13 Dywizjonu Artylerii Konnej ppłk. Janusza Grzesły. Wymarsz pododdziałów 31 pSK z dotychczasowych miejsc postoju w Puszczy Mariańskiej nastąpił zapewne jeszcze wieczorem 10 września i w godzinach nocnych dotarły one w rejon miejscowości Studzieniec. Stąd podjęły marsz wzdłuż osi Żuków-Wólka Wręcka-Świnice, ubezpieczane przez kilka patroli konnych. $\mathrm{Na}$ przodzie kolumny znajdowali się także żołnierze plutonu pionierów oraz plutonu przeciwgazowego, którzy naprawiali uszkodzone mostki i przepusty wodne ${ }^{23}$. Nocny marsz tak zapamiętał kpr. Stanisław Świerczyński, jeden z żołnierzy pułkowego plutonu artylerii:

\footnotetext{
kampanii wrześniowej 1939 r., Warszawa 1985, s. 176; W. Тномме́E, Oni uratowali honor Armii "Eódż”, „Wrocławski Tygodnik Katolików” 1961, nr 2, s. 5.

${ }^{22}$ Jego dowódcą w dniu wybuchu wojny był por. Witold Szpilewski, lecz zaginął on w trakcie walk prowadzonych 3 września, wobec czego dowództwo plutonu objął sierż. Stanisław Dobrakowski.

${ }^{23}$ PSZ, t. 1, cz. 3, s. 152-154 i 175; K.L. GALSTER, Ksiega pamiątkowa artylerii polskiej 19141939, Londyn 1975, s. 287; Artyleria konna w kampanii wrześniowej 1939 roku. Książka pamiątkowa,
} 
Była godzina 3 a może 4 po północy. Z zamyślenia wyrwał mnie głos dowódcy plut. art. sierżanta Dobrakowskiego, który dowodził naszym plutonem już od trzeciego dnia wojny, gdyż dotychczasowy dowódca plutonu art. por. Szpilewski zaginął bez wieści podczas nocnych walk w pasie granicznym - w rejonie Gruszczyc i Błaszek. Otrzymałem rozkaz niezwłocznego maszerowania z działonem ze szpicą w kierunku miasta Mszczonowa. Wydałem krótką komendę i zaprzęgi ruszyły za mną w nakazanym kierunku. Za nami poszły pozostałe kolumny naszego wojska. W półmroku dostrzegłem idącego również w straży przedniej dowódcę pułku, ppłk. Wnuka ${ }^{24}$.

Z kolei por. Zenon Janiak (dowódca 7 kompanii strzeleckiej) tak wspominał ową noc: „Ruszamy. Główny trakt zostawiamy z boku. Maszerujemy na przełaj najkrótszą drogą. Noc ciemna. Żołnierze posuwają się jak duchy... słychać bicie własnego serca. Podchodzimy pod pierwsze zabudowania Mszczonowa"25.

Tuż przed wkroczeniem do miasteczka żołnierze otrzymali rozkaz zachowania bezwzględnej ciszy, by uderzyć na Niemców z zaskoczenia. W tym celu zdjęto broń maszynową z biedek i niesiono ją na plecach, wykorzystując do ukrycia swej obecności przed wrogiem wszelkie naturalne przeszkody (np. niewielkie zagajniki) oraz nocne ciemności. Oto jak te chwile zapamiętał jeden z żołnierzy: „Kazałem zdjąć cekaemy z wózków, żeby nie było terkotu, chrzęstu uprzęży, nieśliśmy sprzęt na plecach i tak po cichu doszliśmy do rogatek Mszczonowa"26. Dzięki temu około godziny 4.00 polscy żołnierze zdołali niepostrzeżenie dotrzeć do pierwszych zabudowań miasteczka, z czego pewni siebie Niemcy nie zdawali sobie sprawy, do chwili rozpoczęcia ataku. Nastąpił on jeszcze przed świtem i był zaskoczeniem dla żołnierzy wroga, którzy nie spodziewali się obecności większych sił polskich w najbliższej okolicy. Owa pewność siebie była o tyle dziwna, iż Mszczonów pełnił ważną rolę nie tylko jako miejsce krzyżowania się kilku szos, lecz także jako punkt etapowy niemieckiego XVI Korpusu

oprac. J. Boguski, Londyn 1976, s. 231; W. JARno, Strzelcy Kaniowscy w latach 1919-1939, Warszawa 2004, s. 297; W. ADAMSKI, Kampania wrześniowa 193931 putku Strzelców Kaniowskich w relacjach oficerów 31 pSK, Kozienice 2009, s. 19 - relacja por. Czesława Jarmickiego, dowódcy plutonu pionierów z 18 III $1946 \mathrm{r}$.

${ }^{24}$ ZKRPWP w Łodzi, sygn. 740, S. Świerczyński, Wspomnienia dziatonowego z kampanii wrześniowej. Bój o Mszczonów 31 Putku Strzelców Kaniowskich, k. 3.

${ }^{25}$ Wrześniowe wspomnienia porucznika Zenona Janiaka. Pamiętnik dowódcy 7. kompanii strzeleckiej 31 putku Strzelców Kaniowskich z Września 1939 roku, red. i oprac. B. RosıńsKI, M. BEDNAREK, K. ZAJĄC, Łódź-Kozienice 2018, s. 98-100.

26 T. Gicgier, Wojenne drogi, „Odgłosy” 1979, nr 35, s. 11. 
Armijnego. Tej nocy przebywały w nim pododdziały tyłowe i służby zaopatrujące m.in. 1 i 4 DPanc. oraz 31 DP. Liczne samochody ciężarowe oraz cysterny były rozlokowane w różnych punktach miasteczka, co ułatwiło polskim żołnierzom atak z zaskoczenia.

W straży przedniej 31 pSK poruszali się piechurzy I batalionu - drogą od strony Świnic (kilka kilometrów na zachód od Mszczonowa) - wspierani przez część pododdziałów III batalionu, pułkowy pluton artylerii oraz działa 3 baterii 10 pal. Według S. Świerczyńskiego dowódcą straży przedniej był kpt. K. Skorupski, który kierował grupą wkraczającą niepostrzeżenie dla Niemców do miasteczka. Polscy żołnierze poruszali się ul. Żyrardowską - docierając po cichu do kościoła pw. św. Jana Chrzciciela, położonego po zachodniej stronie ówczesnego placu Piłsudskiego (obecnie Park Saski). Natomiast pozostałe siły (III batalion oraz pozostałości II batalionu) osłaniały natarcie, ubezpieczając je ze skrzydeł ${ }^{27}$.

Właściwe natarcie poprzedzone zostało ogniem artyleryjskim haubic III dywizjonu 10 pal, który zaskoczył niespodziewających się natarcia Niemców. Podobno dowódca 31 pSK był przekonany, iż 30 DP gen. bryg. L. Cehaka opanowała już Mszczonów i jedynie z przezorności ostrzelano miasteczko z dział, koncentrując ogień na drogach wylotowych. W rzeczywistości jednak dywizja ta - jak wcześniej podano - poniechała uderzenia na miasteczko, które wciąż pozostawało w rękach Niemców. Godzina ataku nie jest do końca jasna. Według kpt. Aleksandra Ogrodnika, I adiutanta pułku, starcia miały się rozpocząć już około godziny 2.00. Informacja ta budzi wiele wątpliwości, gdyż w części relacji jest mowa, iż atak nastąpił tuż przed świtem. Ponieważ wschód słońca tego dnia miał miejsce o godzinie 5.25 - toteż najprawdopodobniej walki o Mszczonów rozpoczęły się po godzinie 4.00 , a być może nawet koło godziny 5.00 , jak z kolei twierdził por. Czesław Jarmicki ${ }^{28}$.

Wykorzystując panujące jeszcze ciemności żołnierze I batalionu wkroczyli przed świtem niepostrzeżenie dla Niemców do miasteczka. Dowodzący 1 kompanią strzelecką kpt. Władysław Czyż tak opisał owe chwile:

27 P. ZARZycki, op. cit., s. 33; W. AdAmSKi, op. cit., s. 61 - relacja kpt. K. Skorupskiego, dowódcy III batalionu z 15 X 1945 r.

${ }_{28}$ W. JARno (Strzelcy..., s. 297) podal, że nastąpiło to jeszcze w ciemnościach - o godzinie 4.00; W. AdAMSKI, op. cit., s. 19 - relacja por. C. Jarmickiego z 18 III 1946 r. (tu mowa, iż atak nastąpił o świcie), s. 43 - relacja kpt. A. Ogrodnika, 1 adiutanta 31 pSK - brak daty (tu podano, iż oddziały polskie wkroczyły do Mszczonowa około godz. 2.00), s. 61 - relacja kpt. K. Skorupskiego, dowódcy III batalionu z 15 X 1945 r. (tu jedynie informacja, iż atak na miasto rozpoczął się przed świtem). 
Pół godziny przed świtem weszliśmy do Mszczonowa. Na rynku zauważyłem dużo aut, które przygotowywały się do odjazdu, między nimi były i czołgi. Zorientowałem się, że są to Niemcy. Wydałem rozkaz karabinowemu z CKM i działka p-panc. do otwarcia ognia. Ppor. Dębskiemu dałem rozkaz posuwania się z plutonem wzdłuż murów i obrzucenia aut granatami. Z resztą kompanii wyruszyłem biegiem skrajem miasteczka, aby odciąć u wylotu wyjście samochodom. Walka trwała około godziny ${ }^{29}$.

Pierwsze chwile walk szczegółowo ukazują również wspomnienia kpr. S. Świerczyńskiego, dowódcy działonu w pułkowym plutonie artylerii:

Doszliśmy do pierwszych zabudowań miasteczka. Wąska uliczka od strony Żyrardowa prowadziła do rynku, gdzie krzyżowały się główne drogi. Zatrzymaliśmy się. Nastała chwila milczenia i wyczekiwania. Wreszcie błysnęła nad miastem rakieta, umówiony znak, że kapral Ciupek ze szperaczami doszedł do wyznaczonego miejsca. Dowódca straży przedniej [kapitan Skorupski, dowódca III batalionu i 8 kompanii 31 pSK - dop. W.J.] dał rozkaz do ataku. Ruszyłem galopem. Przy zbiegu ulicy z rynkiem zatrzymałem działon z jednoczesną komendą do odprzodkowania. Tu pozostały zaprzęgi z przodkami, również jaszcz, natomiast samą armatę wtoczyliśmy na rynek. Biegiem doniesiono skrzynię z amunicją. Cały ten manewr odbył się szybko i cicho ${ }^{30}$.

Trzeba tu przypomnieć, iż przemieszczaniu armat zazwyczaj towarzyszyły głośne odgłosy, toteż aby je zminimalizować przed walką, kanonierzy owinęli żelazne koła szmatami, osłonę dział zaś w trakcie ich przetaczania na stanowiska ogniowe zapewniły karabiny maszynowe z 3 kompanii CKM por. Antoniego Malanowicza. Moment ataku tak opisał kpt. K. Skorupski, dowódca III batalionu 31 pSK: „Przed świtem dochodzimy pod Mszczonów. Idę z baonem jako drugi. I baon wsparty ogniem dyonu art. wchodzi do Mszczona obsadzonego przez Niemców (...) Niemcy są zaszokowani. W miasteczku nagromadzili duże ilości broni pancernej, samochodów, benzyny, amunicji i żywności”31. Z kolei inny żołnierz 31 pSK tak zapamiętał początek walk:

Uderzyliśmy na Mszczonów pod osłoną naszej artylerii. Wdarliśmy się do miasta i ustawialiśmy zaraz karabiny maszynowe na wszystkich skrzyżowaniach i wylotach

${ }^{29}$ CAW WBH, Kampania wrześniowa, sygn. II.3.13, Relacja kpt. W. Czyża z działań 31 pSK, brak paginacji.

30 ZKRPWP w Łodzi, sygn. 740, S. Świerczyński, Wspomnienia dziatonowego..., k. 3-4.

31 W. AdAmski, op. cit., s. 61 - relacja kpt. K. Skorupskiego, dowódcy III batalionu, z 15 X $1945 \mathrm{r}$. 
dróg. (...) Zrobiliśmy duże zamieszanie na tyłach niemieckich, bo oni sądzili, o czym dowiedziałem się później, że nasze działanie pod Mszczonowem odbywa się w powiązaniu z natarciem generała Kutrzeby spod Kutna i Bzury ${ }^{32}$.

Niespodziewany atak polskich żołnierzy zaskoczył Niemców, którzy - nie spodziewając się zagrożenia - nie zadbali o odpowiednie środki ostrożności i wystawienie patroli ubezpieczających. O grożącym niebezpieczeństwie zorientowali się dopiero, gdy polscy piechurzy dotarli do centrum miasteczka. Wywołało to trudną do opanowania panikę, spotęgowaną ostrzałem ogniowym haubic III dywizjonu 10 pal dróg wylotowych, którymi część Niemców próbowała się wycofać. Równie ważne zadanie powierzono jednemu z dwóch dział pułkowego plutonu artylerii, które ustawiono tuż za miastem, w celu blokowania żołnierzom wroga możliwości wydostania się z Mszczonowa drogą w kierunku Skierniewic (działonem tym dowodził plut. Urbaniak - imienia nie ustalono). Drugi działon tego plutonu dowodzony przez kpr. S. Świerczyńskiego skierowano do bezpośredniego wsparcia polskiego ataku na Mszczonów ${ }^{33}$.

W trakcie walk o miasteczko doszło do gwałtownego starcia w samym jego centrum, czyli w rejonie ówczesnego placu Józefa Piłsudskiego. Jako pierwsi wdarli się do Mszczonowa żołnierze 1 kompanii strzeleckiej kpt. W. Czyża, którzy z zaskoczenia zniszczyli kilka gniazd niemieckiej broni maszynowej w rejonie kościoła. Nagła i gwałtowna strzelanina była sygnałem dla kpt. A. Ogrodnika, adiutanta dowódcy 31 pSK, by nakazać sierż. S. Dobrakowskiemu (dowódcy pułkowego plutonu artylerii) skierowanie się niezwłocznie, wraz z działonem kpr. S. Świerczyńskiego, na rynek. Tam - po zajęciu stanowiska ogniowego - ostrzelano czołg niemiecki (jak to określono w relacji - „duży”), a po jego zniszczeniu obsługa działa przeciwpancernego Bofors $37 \mathrm{~mm}$ kierowana przez ppor. Stanisława Piekarczyka, dowódcę 3 plutonu kompanii przeciwpancernej 31 pSK, miała zniszczyć drugi „duży” czołg, stojący w pobliżu pierwszego. Podobnie to zdarzenie przestawił inny uczestnik tych walk, ppor. Aleksy Stanisław Rżewski, dowódca działonu artylerii przeciwpancernej:

32 T. GICGIER, op. cit., s. 11.

${ }^{33}$ ZKRPWP w Łodzi, sygn. 648. Relacja kpt. C. Jarmickiego, k. 4-5; sygn. 782. Relacja Henryka Majera, k. 5; PSZ, T. 1, cz. 3, s. 146-147, 152, 157 i 174-175; J. WRÓBLEWSKI, op. cit., s. 274275; L. Głowacki, op. cit., s. 176-177; P. Zarzycki, op. cit., s. 33; A. Malanowicz, Opowieść o konajacym żotnierzu, „Za Wolność i Lud” 1980, nr 44, s. 11. 

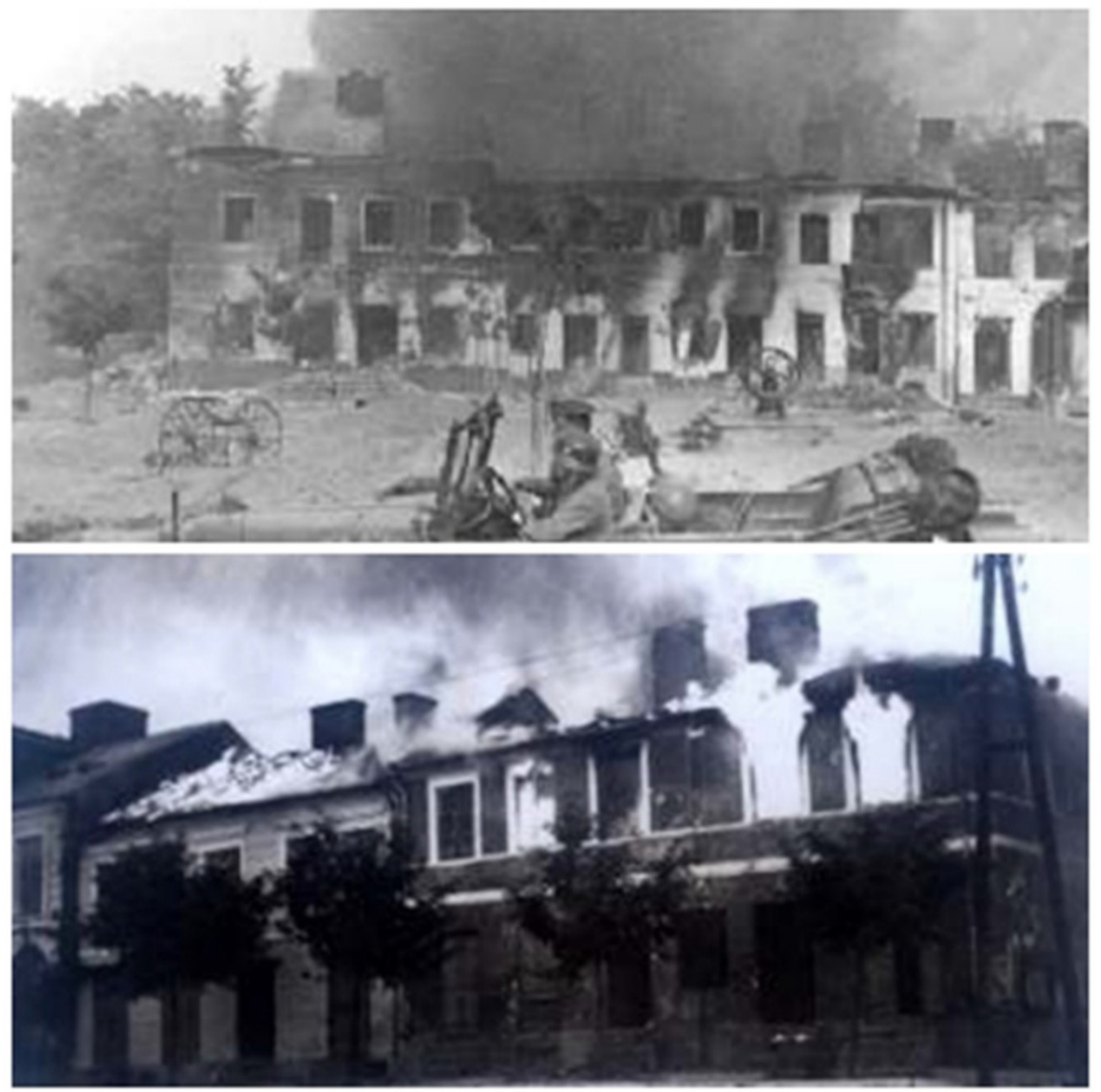

Ryc. 3-4. Niemcy na Placu Piłsudskiego (widok na ścianę zachodnią) i płonące budynki na Placu Piłsudskiego (źródło: „Merkuriusz Mszczonowski” 2007, nr 8 (130), s. 6 i 16)

Nierówną drogą, kolebiąc się z gąsienicy na gąsienicę szły dwa lekkie czołgi. Za nimi posuwał się ciężarowy samochód. Kiedy czołgi zbliżyły się na odległość stu pięćdziesięciu metrów, otworzyliśmy do nich ogień. Pierwszy pocisk trafił w boczny pancerz poniżej wieży. Czołg skręcił gwałtownie, stając w poprzek drogi. Nikt z niego nie wyszedł. Nie było czasu na radość z sukcesu, bo zbliżała się druga maszyna. Parła z największą prędkością, bezustannie prowadząc ogień z karabinu maszynowego. Nierówna droga i duża prędkość sprawiły, że strzały były niecelne, tylko odpryski cegieł grzechotały po hełmach. I znowu komenda: „W czołg - ognia!”. Silny wybuch i wydobywający się z czołgu kłąb dymu świadczyły, że ten pojazd został także trafiony. Spoza dymnej chmury widać było wycofujący się samochód. Nasza sprytnie ukryta armatka spełniła zadanie. (...) Część broniących 
się, choć zaskoczonych Niemców zdążyła dopaść swoich samochodów i czołgów. Gniotąc i rozbijając własne pojazdy, starali się jak najszybciej wydostać z miasta. Stąd czołgi, które trafiły na nasze stanowisko ${ }^{34}$.

Z kolei według kpt. K. Skorupskiego, dowodzącego III batalionem 31 pSK, istotną rolę $\mathrm{w}$ walce $\mathrm{z}$ niemieckimi czołgami odegrać miały armaty z 3 plutonu pułkowej kompanii przeciwpancernej ${ }^{35}$. Szczegóły tego starcia są jednak różnie przedstawiane, czego przykładem może być powojenna relacja kpr. S. Świerczyńskiego, dowódcy działonu pułkowego plutonu artylerii:

Stanowisko dla działa wybrałem po północnej stronie rynku. Był to mały plac w formie kwadratu, otoczony z czterech stron budynkami, pośród których górował kościół z jedną wieżą, usytuowany narożnie przy ulicy wiodącej do Piotrkowa Tryb. Po przeciwnej stronie ryneczku, u wylotu ulicy w lewym narożniku (ob. ul. Sienkiewicza) stał niemiecki czołg. Kilka metrów dalej, był widoczny tył drugiego czołgu $^{36}$.

Obsługa armaty szybko opanowała zdenerwowanie, wzięła na cel pierwszy z czołgów i dwoma strzałami zniszczyła go, po czym unieszkodliwiła drugi „duży” czołg, a następnie dwie niemieckie ciężarówki. Jak widać obie wersje są rozbieżne w kwestii, z którego działa zniszczono wspomniany drugi czołg. Podobnych wątpliwości w odniesieniu do szczegółowego przebiegu walk jest wiele i trudno je jednoznacznie rozstrzygnąć. Prawdopodobnie pierwszym zniszczonym pojazdem był lekki czołg Panzerkampfwagen II, drugim zaś czołg średni Panzerkampfwagen IV uzbrojony w krótkolufowe działo $75 \mathrm{~mm}$.

Celny ogień działonu kpr. S. Świerczyńskiego skutecznie wsparł działania piechurów. Jednak Niemcy - ochłonąwszy z zaskoczenia - zaczęli stawiać opór i ostrzeliwać pobliskie zabudowania w rynku. Dodatkowo do walki włączyła się niemiecka bateria stacjonująca poza miastem, której pociski zaczęły spadać na centrum miasteczka. Niebawem w jego kierunku nadjechało kilka kolejnych czołgów wroga (co najmniej cztery, w tym jeden czołg średni Panzerkampfwagen IV), których posuwanie powstrzymał ogień działonu kpr. S. Świerczyńskiego. Szybko jednak wystrzelano niemal wszystkie pociski, toteż gdy pozostały dwa ostatnie - kilku ludzi z obsługi działa pobiegło po następną skrzynkę

34 A.S. RżewSKi, Pamiętnik jeńca, Łódź 1986, s. 12.

35 W. Adamski, op. cit., s. 61 - relacja kpt. K. Skorupskiego, dowódcy III batalionu, z 15 X $1945 \mathrm{r}$.

${ }^{36}$ ZKRPWP w Łodzi, sygn. 740, S. Świerczyński, Wspomnienia dziatonowego..., k. 4. 


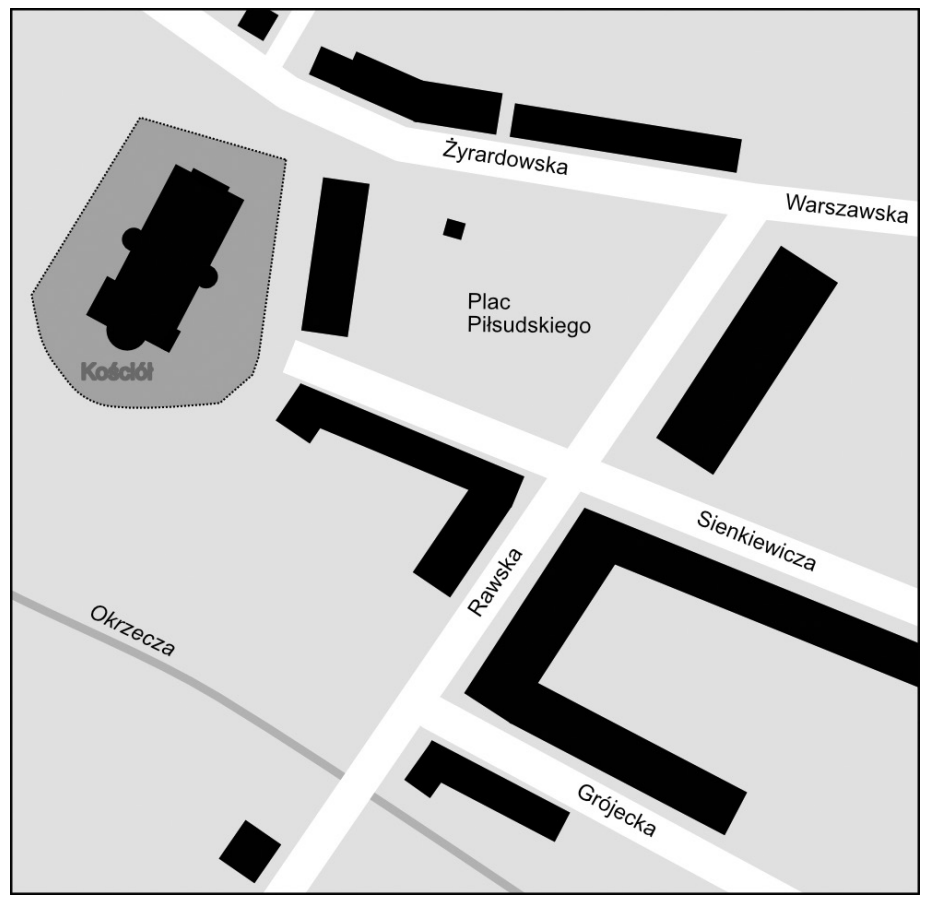

Ryc. 5. Szkic centrum Mszczonowa w roku 1939 (rys. T. Grabarczyk)

z pociskami, celowniczy odprowadził zaś zranionego ładowniczego do pobliskiego punktu opatrunkowego. Przy armacie pozostał sam kpr. S. Świerczyński. Wówczas niespodziewanie jeden z niemieckich czołgów podjął kolejną próbę wjechania na rynek. Dalsze chwile tak opisał dowódca działonu:

Przy dziale byłem sam. Znałem je dobrze, więc zdecydowałem się działać jak najszybciej. Nadrzuciłem drążkiem w kierunku jadącego czołgu, nastawiłem przyrządy celownicze, otworzyłem zamek, chwyciłem pocisk ze skrzyni i załadowałem. W tym momencie przybiegł z pomocą sierżant Dobrakowski i wyręczając mnie, zamknął zamek. Czołg był już pośrodku rynku, bardzo blisko, bo około 50 metrów przed lufą armaty. Najwyższy czas. Szarpnąłem za sznurek. Wystrzał. Rozległ się donośny huk i odgłos bliskiego uderzenia. Szczęk łamanego żelaza i zwiększony warkot motoru zlały się w jeden krótki zgrzyt i wszystko ucichło ... Przez opadający dym zobaczyłem podnoszącą się pokrywę czołgu, z włazu wyłoniła się postać niemieckiego czołgisty z granatem w podniesionej ręce. Sięgnąlem po „Visa”, ale nie zdążyłem wycelować w Niemca, który zeskakując na ziemię - rzucił grantem w moją stronę. Granat upadł w połowie drogi między czołgiem i armatą. Pochyliłem się za tarczą działa. Część odłamków przeleciała ze świstem nad moją głową, 
inne uderzyły o tarczę. (...) Rozbity olbrzym stał na samym środku rynku. Okazało się, że był to ostatni z atakujących nas czołgów w tej bitwie. (...) Radość ze zwycięstwa udzieliła się wszystkim walczącym. Rynek wypełniali tłumnie nasi żołnierze. Słabnące odgłosy walki z sąsiednich uliczek, świadczyły o udanym ataku na nieprzyjaciela ${ }^{37}$.

Niewątpliwie działon kpr. S. Świerczyńskiego odegrał w wałkach ważną rolę i zniszczył kilka pojazdów wroga, jednak - jak wspomniano - ustalenie precyzyjnych szczegółów w tej kwestii jest niezmiernie trudne. Część zniszczonych pojazdów miała bowiem ślady trafienia pocisku armatniego $37 \mathrm{~mm}$, co może wskazywać, iż były ostrzeliwane zarówno z armat przeciwpancernych, jak i armat pułkowego plutonu artylerii. Ze szczegółowej relacji kpr. S. Świerczyńskiego wynika, iż jego działon zniszczył wówczas trzy czołgi oraz dwa samochody ciężarowe - lecz jak wcześniej podano, trudno tę informację zweryfikować.

Żołnierze II i III batalionu 31 pSK - po włączeniu się do walki - zaczęli zwalczać Niemców broniących się w budynkach położonych w pobliżu rynku, którzy pod impetem polskiego natarcia podjęli próbę wycofania się z centrum miasteczka ku jego południowej części, szosą w kierunku Rawy Mazowieckiej. Byli oni ścigani przez polskich piechurów, którzy mieli zniszczyć niemiecką baterię na południowym krańcu Mszczonowa. Następnie żołnierze III batalionu kpt. K. Skorupskiego skierowali się w stronę wschodniego przedmieścia miasteczka, gdzie - jak sam wspomina - odkryto: „koło cmentarza - olbrzymi park samochodów z czołgami, benzyną i amunicją. Zatrzymuję się, by to zniszczyć oraz zlikwidować tych Niemców, którzy walczyli z nami na cmentarzu"38.

Jednocześnie trwało oczyszczanie miasteczka z żołnierzy niemieckich, czym zajęli się strzelcy III batalionu 31 pSK, co tak wspominał por. Z. Janiak, dowódca 7 kompanii strzeleckiej:

Kompania otrzymuje rozkaz oczyszczania miasta. Upojeni sukcesem żołnierze biją się na śmierć i życie... Ulice zbryzgane krwią... Z okien domów padają strzały... Nawet z wieży kościelnej sypią się wiązki pocisków fosforycznych. Jestem zbłocony, spocony, splamiony krwią. Nie zważając na nic, biegam po ulicach od osłony do osłony. Zapomniałem w tym momencie, że istnieje śmierćs ${ }^{39}$.

37 Ibidem, k. 6

38 W. AdAmsKi, op. cit., s. 61 - relacja kpt. K. Skorupskiego, dowódcy III batalionu, z 15 X 1945 r.

39 Wrześniowe wspomnienia porucznika..., s. 100. 

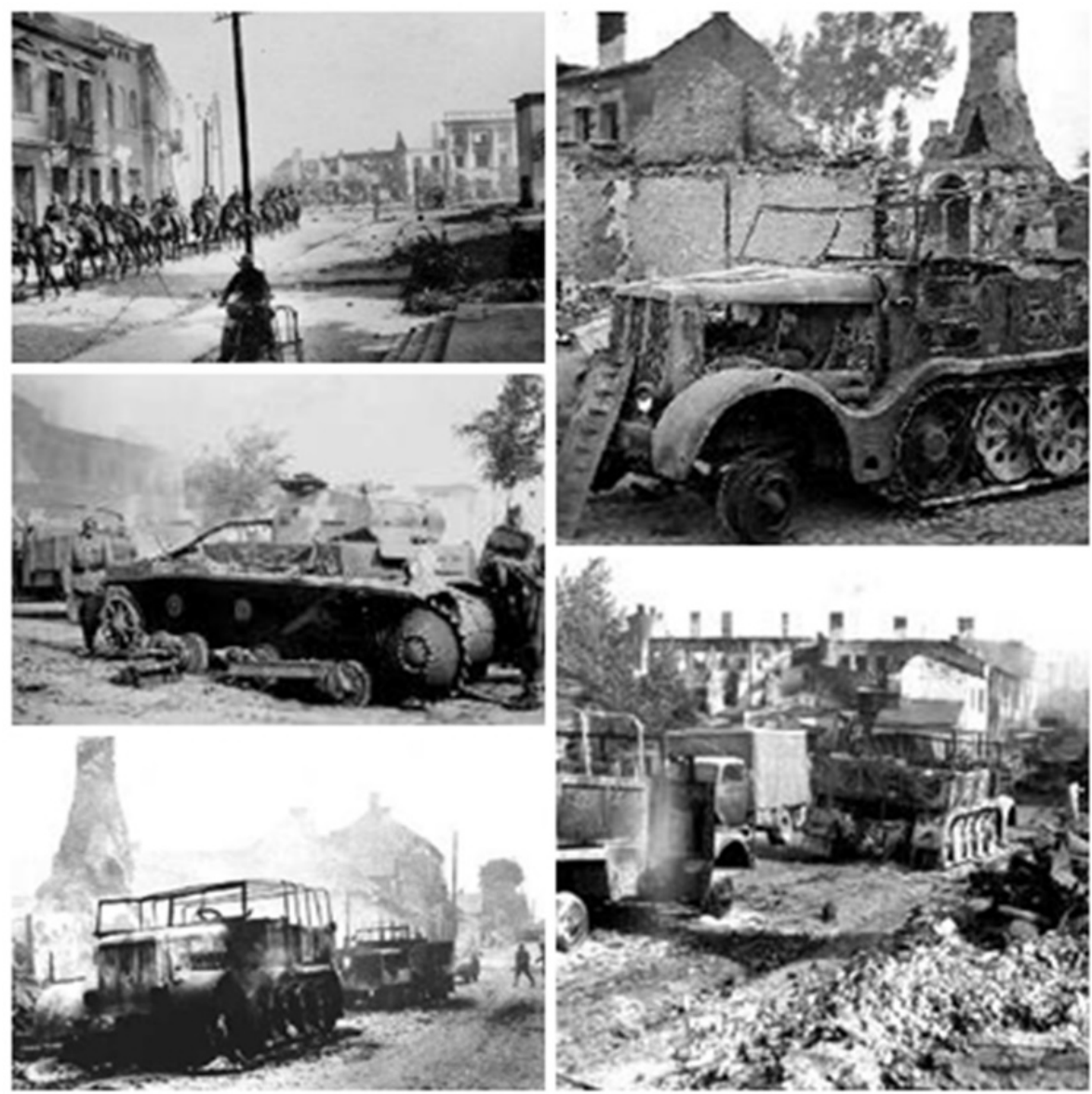

Ryc. 6-10. Zdjęcia w lewej kolumnie: ulica Żyrardowska - widok na zniszczony ratusz, zniszczony niemiecki czołg na Placu Piłsudskiego (kamienice w tle stanowią ścianę zachodnią zabudowań placu) i zniszczone niemieckie pojazdy na ulicy Rawskiej; zdjęcia w prawej kolumnie: zniszczony niemiecki ciągnik artyleryjski na ulicy Rawskiej i zniszczone niemieckie pojazdy na ulicy Rawskiej (źródło: „Merkuriusz Mszczonowski” 2007, nr 8 (130), s. 9, 13, 14 i 24)

Według relacji por. Czesława Jarmickiego, dowódcy plutonu pionierów, w likwidowaniu punktów oporu wroga brali aktywny udział również żołnierze podległego mu plutonu oraz plutonu przeciwchemicznego ${ }^{40}$.

${ }^{40}$ W. AdAmSKI, op. cit., s. 20 - relacja por. C. Jarmickiego, dowódcy plutonu pionierów, z 18 III $1946 \mathrm{r}$. 
Atak polskich żołnierzy na Mszczonów był dla kwaterujących tu Niemców zaskoczeniem, toteż w powstałym chaosie próbowali desperacko wycofać się z miasteczka - ponieśli jednak przy tym duże straty w ludziach i sprzęcie. Większości pojazdów mechanicznych (ciężarówki, samochody osobowe i ciągniki artyleryjskie) nie zdołali ewakuować i stały się one łupem polskich żołnierzy. Oprócz wspomnianego wcześniej parku samochodowego za cmentarzem strzelcy 31 pSK zdobyli wiele pojazdów mechanicznych w centrum Mszczonowa, rozlokowanych na terenie kilku posesji położonych, co tak opisał cytowany powyżej por. Z. Janiak:

W jednym podwórzu stoi kilkanaście cudownych samochodów osobowych. Melduję o tym. Otrzymuję rozkaz spalenia wszystkiego (ze względu na to, że nie było gdzie odstawić łupu wojennego). Nim wróciłem, żołnierze pozabierali z samochodów prywatny dobytek, pozostawiony przez uciekinierów. Było tam wszystko, czego dusza zapragnie. Silniki były już poprzestrzeliwane. Po paru minutach samochody stoją w płomieniach. Aż mnie serce ściskało, patrząc na płonące wspaniałe limuzyny [w tym wypadku chodziło zapewne o samochody użytkowane przez niemieckich dowódców i sztabowców - dop. W.J.]. (...) Na drodze stały wozy ciężarowe. Żołnierze bez rozkazu już samorzutnie podpalali zbiorniki na naftę, samochody z amunicją itd. Podpalali w ten sposób, że przestrzeliwali zbiornik $\mathrm{z}$ benzyną ${ }^{41}$.

Równie ciekawą wzmiankę $\mathrm{w}$ tej kwestii zawierają wspomnienia kpt. C. Jarmickiego:

Wiele samochodów zagarażowanych w podwórkach nie zdążyli [Niemcy - dop. W.J.] uruchomić. D-ca pułku ppłk Wnuk osobiście rozkazał mi podpalić cały ten sprzęt. Od podpalonych (oblanych benzyną) samochodów zajęła się sąsiednia stodoła, jak się potem okazało magazyn amunicji. Po opuszczeniu Mszczonowa słyszeliśmy duże detonacje dochodzące z tej właśnie stodoły ${ }^{42}$.

O skali sukcesu żołnierze 31 pSK mogli się przekonać po wschodzie słońca, gdy walki w Mszczonowie wygasły. Niestety, duża część informacji o stoczonym boju jest niespójna bądź wręcz rozbieżna - stąd też dane o stratach niemieckich, jak i własnych, budzą wątpliwości. Te ostatnie musiały być jednak znaczne,

${ }^{41}$ Wrześniowe wspomnienia porucznika..., s. 100.

${ }^{42}$ W. AdA mSKI, op. cit., s. 20 - relacja por. C. Jarmickiego, dowódcy plutonu pionierów, z 18 III $1946 \mathrm{r}$. 
skoro w dzienniku niemieckiej 4 DPanc. pod datą 11 września napisano, iż rozpoczął się on:

O godziny 4.00 napadem na własne i obce służby zaopatrzenia w Mszczonowie. Polskie oddziały szacowane na siłę pułku, przy tym artyleria, wdarły się do miasta z północnego-zachodu z lasów. Wspierali je uzbrojeni cywile [w rzeczywistości tacy w walce nie brali udziału, chyba że uznamy za to wskazywanie strzelcom 31 pSK miejsc kwaterunku żołnierzy niemieckich - dop. W.J.]. W ciężkiej walce ogniowej ucierpiała szczególnie kompania warsztatowa 36 ppanc. Straty w ludziach i materiale. Miasto stanęło w płomieniach ${ }^{43}$.

Również polscy historycy podają na ten temat ogólnikowe dane, gdyż - dla przykładu - Marian Porwit napisał enigmatycznie, iż spalono zdobyte samochody (bez podania ich liczby) oraz wysadzono przejętą amunicję ${ }^{44}$. Także Apoloniusz Zawilski nie poświęcił walce o Mszczonów wiele miejsca, pisząc: „Polacy przy minimalnych stratach własnych wybili wielu Niemców oraz zniszczyli przez podpalenie benzyny i wysadzenie składu amunicyjnego dużo sprzętu”־5; podobnie jak i Mieczysław Bielski, który zwrócił uwagę: „Straty Niemców były duże. Zapasy benzyny ułatwiły spalenie zdobytego sprzętu. W powietrze wysadzono składy amunicyjne, a zdobyta żywność oraz mapy z nakreśloną sytuacją wojsk niemieckich okazały się bezcenne"’36.

Bardziej szczegółowe informacje na temat strat niemieckich zawierają wspomnienia polskich żołnierzy uczestniczących w boju o Mszczonów, lecz są one zazwyczaj rozbieżne w tej kwestii. Sierżant S. Dobrakowski (dowódca pułkowego plutonu artylerii) stwierdził: „Była bitwa o Mszczonów i tam w jednej z ulic zniszczyliśmy około 15 czołgów niemieckich, o czym to może Pan [kpt. A. Ogrodnik - dop. W.J.] sam opisać jak to było" ${ }^{377}$. Według relacji kpt. A. Ogrodnika straty niemieckie były duże: „Zniszczono około 30 czołgów na chodzie i na transporterach w tym: dwa duże czołgi, kilkanaście samochodów i motocykli oraz spalono cysterny z benzyną, wzięto do niewoli dwóch oficerów i kilkadziesiąt żołnierzy. Kilkunastu było zabitych, a rannych nie brano ze względu na brak miejsca”48 .

${ }^{43}$ Cyt. za: A. WesoŁowski, Podputkownik Wnuk..., s. 327.

${ }^{44}$ M. Porwit, Komentarze do historii polskich dziatań obronnych 1939 roku, cz. 2: Odwrót i kontrofensywa, Warszawa 1983, s. 299.

45 A. Zawilski, Bitwy polskiego Września, Warszawa 1972, t. 2, Warszawa 1989, s. 122.

${ }^{46}$ M. BIELSKI, op. cit., s. 240.

${ }^{47}$ Cyt. za: W. JARno, W. KozŁowsKi, op. cit., s. 233.

48 W. AdAMSKI, op. cit., s. 44 - relacja kpt. A. Ogrodnika, 1 adiutanta 31 pSK - brak daty. 
Z kolei ten sam A. Ogrodnik - w oświadczeniu przesłanym Włodzimierzowi Kozłowskiemu - podał, iż zniszczono około 20 niemieckich czołgów oraz wzięto do niewoli kilkudziesięciu jeńców ${ }^{49}$, zaś w innej relacji stwierdził: „Wzięto do niewoli 2 oficerów, 35 szeregowców oraz kasę oddziału, w której znajdowało się $21.000 \mathrm{mk}$ niemieckich. Zniszczono 3 najcięższe czołgi i 22 lekkie; spalono ok. 20 samochodów ciężarowych i 10 osobowych oraz kilkanaście motocykli”"

Jeszcze inna liczba znalazła się u Piotra Dymeckiego, według którego miano w sumie zniszczyć w trakcie porannych walk w Mszczonowie: „16 czołgów oraz 14 wozów pancernych i ciężarówek" ${ }^{51}$ - ponadto miał także zginąć jeden $\mathrm{z}$ niemieckich dowódców $\mathrm{w}$ randze pułkownika. Jeszcze inne dane na temat niemieckich strat wskazał por. Z. Janiak: „Samochodów ciężarowych zostaje zniszczonych kilkanaście. Na ulicy leży 6 rozbitych czołgów nieprzyjacielskich. Samochody załadowane amunicją wybuchają co chwila" ${ }^{52}$. Warto jeszcze odnotować publikację Piotra Kukuły, w której znalazła się informacja o zniszczeniu przez polskich żołnierzy szesnastu niemieckich czołgów, kilkunastu samochodów (ciężarowych i osobowych) oraz kilku cystern z benzyną ${ }^{53}$. W konsekwencji trudno precyzyjnie określić liczbę czołgów, jaką Niemcy stracili w Mszczonowie, część z nich była bowiem uszkodzona we wcześniejszych walkach (m.in. podczas nieudanego szturmu Warszawy 8 września) i czekała na naprawę, jaką miała przeprowadzić kompania warsztatowa 36 ppanc. Ta zaskoczona polskim atakiem, poniosła duże straty w ludziach (głównie ranni i wzięci do niewoli) oraz sprzęcie. Według autorów monografii 10 DP: „Do rangi symbolu urosła scena: na rynku, gdzie znajdował się stos karabinów rozbrojonych wcześniej żołnierzy polskich, ppłk W. Wnuk przesłuchiwał niemieckich oficerów-jeńców. Niemcy, karmieni propagandowymi materiałami o bestialstwie Polaków, spodziewali się najgorszego" ${ }^{54}$.

Nie sposób pominąć jeszcze jednej ważnej sprawy - w trakcie walk o Mszczonów uwolniono wielu polskich jeńców, jednak precyzyjne określenie ich liczby

49 W. JARno, W. KozŁowsKi, op. cit., s. 233.

50 CAW WBH, Kampania wrześniowa, sygn. II.2.219. Relacja ta została opublikowana: Kpt. A. Ogrodnik, Relacja z okresu Kampanii Wrześniowej 1939 r. 31 putku Strzelców Kaniowskich, „Na Sieradzkich Szlakach” 1995, nr 3 (95), s. 13-16.

51 P. Dymecki, op. cit., s. 18.

52 Wrześniowe wspomnienia porucznika..., s. 102.

53 P. KuKuŁA, op. cit., s. 185.

54 W. JARno, W. KozŁowsKi, op. cit., s. 234. 
jest trudne, ze względu na rozbieżności występujące w literaturze i wspomnieniach. Oto co por. Z. Janiak napisał na ten temat:

Dochodzę do skraju miasta. Słyszę szepty. Nadstawiam ucho i zbliżam się do dużej stodoły o zniszczonym słomianym dachu. Przez chwilę zawahałem się. Było nas trzech, a szepty w stodole zrobiły na mnie wrażenie, że jest większa ilość ludzi. Odbezpieczyłem pistolet... podsuwam się bliżej... pytam: „Kto tam jest?”. Styszę chóralne odpowiedzi: „To my, jeńcy”. Otwieram drzwi i ze stodoły wypuszczam sześćdziesięciu naszych żołnierzy zabranych do niewoli. Radość ich była nieopisana" ${ }^{15}$.

Z kolei kpr. S. Świerczyński stwierdził: „Oswobodzono też około 200 polskich jeńców, pojmanych w dniach poprzednich przez hitlerowskich najeźdźców" ${ }^{56}$. Liczbę tą podali także w swej pracy autorzy monografii $10 \mathrm{DP}$ oraz P. Dymecki ${ }^{57}$.

W trakcie prowadzonych walk Mszczonów został w poważnym stopniu zniszczony, co widać było zwłaszcza w rejonie placu Piłsudskiego i ulicy Rawskiej, gdzie większość zabudowy uległa spaleniu. Zdjęcia ukazujące widok miasteczka z września 1939 r. potwierdzają dramatyzm walk prowadzonych przez żołnierzy 31 pSK, w wyniku których większość budynków w jego centrum poważnie ucierpiała. Dalszych zniszczeń dokonali Niemcy po ponownym zajęciu Mszczonowa

Żołnierze 31 pSK zdobyli także łupy wojenne - wiele pojazdów mechanicznych, amunicję i żywność. Nie mogąc jednak zabrać ze sobą wspomnianej zdobyczy - niemal całą ją zniszczono, poza częścią niezbędnej żywności oraz zdobycznych map, bezcennych dla dalszego odwrotu ${ }^{58}$. Opanowanie Mszczonowa podniosło morale żołnierzy 31 pSK nadwątlone kilkudniowym odwrotem i dodało im wiary w swe siły, zwiększając zarazem ich wolę dalszej walki. Sukces ten okupiono stosunkowo niewielkimi stratami, gdyż w walce polec miało jedynie trzech polskich żołnierzy, kilkunastu zaś odniosło rany. Zdobycie miasteczka przez pododdziały 31 pSK przyniosło pułkowi wojenną chwałę, czego

55 Wrześniowe wspomnienia porucznika..., s. 104.

${ }^{56}$ ZKRPWP w Łodzi, sygn. 740, S. Świerczyński, Wspomnienia dziatonowego ..., k. 7.

57 W. Jarno, W. KozŁowski, op. cit., s. 233; P. Dymecki, op. cit., s. 18.

58 J. WRóblewsKi, op. cit., s. 275. Mapy wydane jednostkom 10 DP w trakcie mobilizacji obejmowały tylko obszar regionu łódzkiego, w konsekwencji czego dalszy odwrót odbywał się niemalże "na ślepo". 

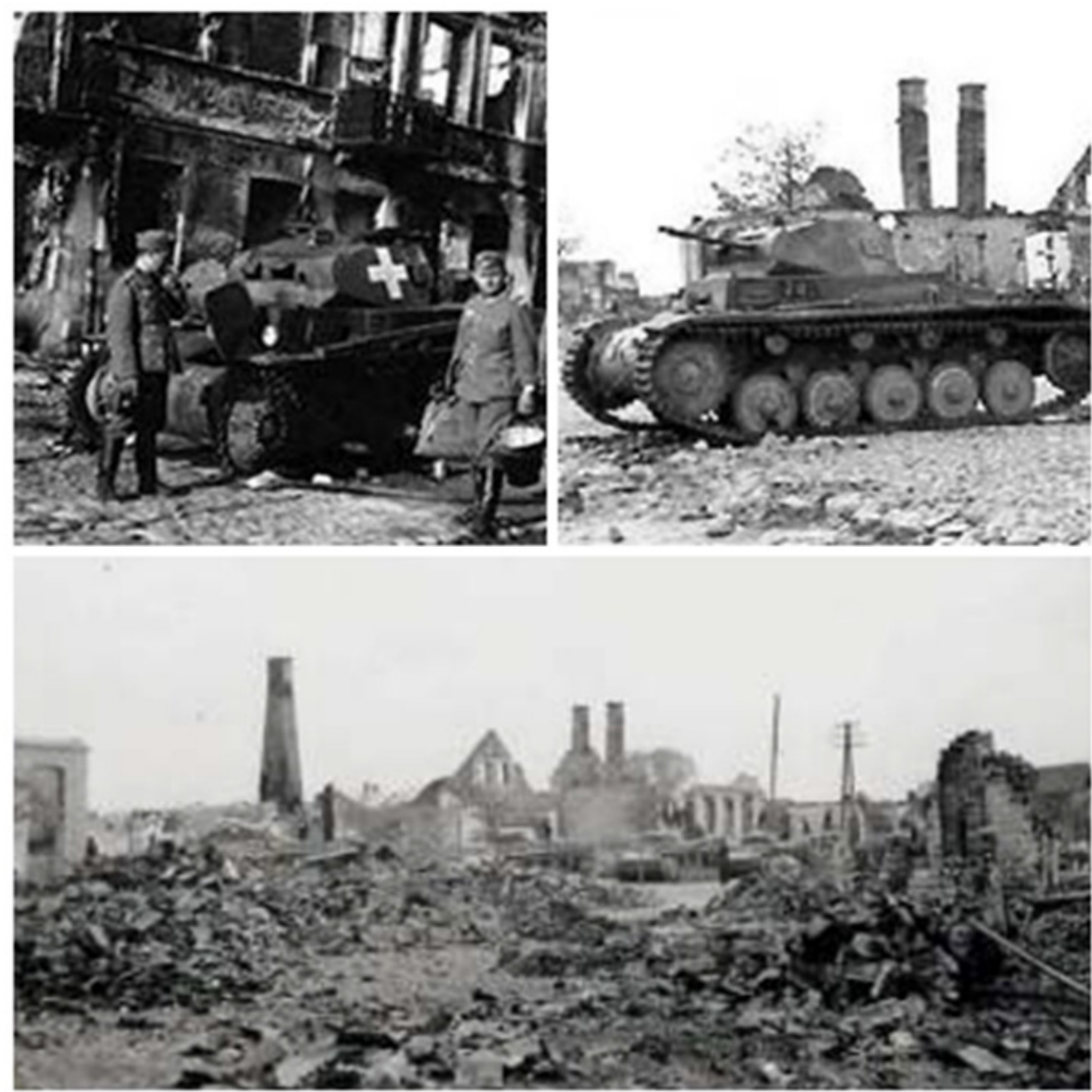

Ryc. 11-13. Zniszczony niemiecki czołg na Placu Piłsudskiego (kamienice w tle stanowią ścianę południową zabudowań placu), wrak niemieckiego czołgu na ulicy Rawskiej i niemieckie czołgi stojące na ulicy Rawskiej (źródło: „Merkuriusz Mszczonowski” 2007, nr 8 (130), s. 14 i 17)

potwierdzeniem było odznaczenie jego sztandaru w 1966 r. Orderem Wojennym Virtuti Militari V klasy (Srebrny Krzyż nr 13274), nadany przez Kapitułę tego odznaczenia w Londynie. Za bój o Mszczonów Orderem Wojennym Virtuti Militari odznaczony został także jego dowódca ppłk Wincenty Wnuk, który 19 października 1967 r. otrzymał Order IV klasy (Krzyż Złoty nr 158) ${ }^{59}$.

59 W. KozŁowski, Ptk Wincenty Wnuk..., s. 821; G. Łukomski, B. Polak, A. Suchcitz, Kawalerowie Virtuti Militari 1792-1945. Wykazy odznaczonych za czyny z lat 1863-1864, 1914-1945, Koszalin 1997, s. 374-375; G. Łunomski, B. Polak, A. Suchcitz, Kawalerowie Virtuti Militari 
Działania polskich żołnierzy doprowadziły - co prawda na krótko - do zamieszania w dowództwie niemieckiego XVI Korpusu Armijnego, które zostało zaskoczone zajęciem Mszczonowa przez 31 pSK, będącego miejscem skrzyżowania kilku ważnych dróg i odgrywającego istotną rolę w niemieckich planach wojennych. Nic więc dziwnego, że w tej sytuacji skierowano niezwłocznie w kierunku Mszczonowa dodatkowe siły, co spowolniło niemieckie działania w rejonie na południe od Warszawy oraz opóźniło forsowanie Wisły w okolicach Góry Kalwarii. Obawiając się, iż utrata Mszczonowa mogła być efektem większego polskiego uderzenia w kierunku Wisły lub południowego brzegu Pilicy, gen. kawalerii E. Höpner (dowódca XVI Korpusu Armijnego) nakazał - około godziny 9.00 - przegrupować w okolice wspomnianego miasteczka część podległych mu sił, celem jego odzyskania. Wśród nich były: z 1 DPanc. - 1 Brygada Pancerna płk. Josefa Harpego, 1 batalion motocyklistów i jeden dywizjon artylerii z 73 Pułku Artylerii, z 4 DPanc. - 7 dywizjon rozpoznawczy mjr. Karla Marzahena, zaś z 31 DP - 12 pp płk. Hugo Ribsteina. Dodatkowo niemieckie natarcie miały wesprzeć z kierunku wschodniego pozostałe siły $31 \mathrm{DP}$ (w tym 17 pp płk. Friedricha Neumanna i 31 Pułk Artylerii płk. Angelo Müllera), podczas gdy 82 pp płk. Gerharda Bertholda miał w rejonie Piaseczna osłaniać działania dywizji. Ponadto od południa w kierunku Mszczonowa przemieszczała się niemiecka 19 DP gen. por. Günthera Schwantesa (z XI Korpusu Armijnego gen. artylerii Emila von Leeba - korpus został czasowo przekazany przez dowództwo Grupy Armii „Południe” pod rozkazy dowódcy 8 Armii gen. piechoty Johannesa Blaskowitza) ${ }^{60}$.

Po opanowaniu Mszczonowa patrole szybko doniosły ppłk. W. Wnukowi o zbliżaniu się silnych oddziałów niemieckich, mających zdecydowaną przewagę nad 31 pSK. W tej sytuacji nie pozostawało nic innego, jak opuścić miasteczko. Po uzupełnieniu podstawowych braków (żywność i amunicja) oraz zniszczeniu zdobycznego sprzętu, żołnierze polscy tuż po godzinie 9.00 wyruszyliw kierunku kompleksu leśnego położonego na północ od Grzegorzewic $(10 \mathrm{~km}$ na wschód od Mszczonowa). Moment ten tak zapamiętał kpr. S. Świerczyński:

1792-1945, t. 3: 1939, cz. 1, Koszalin 1997, s. 147; Żotnierze września..., s. 326; Order Virtuti Militari, red. K. Filipow, G. Jasiński, Warszawa 2013, s. 251. Podpułkownik W. Wnuk otrzymał w 1921 r. Order Wojenny Virtuti Militari klasy V (nr 1877) za czyny wojenne wykazane w trakcie swej służby w 8 pp Legionów (CAW WBH, Kolekcja Virtuti Militari, Wincenty Wnuk, sygn. I.482.69-6130).

${ }^{60}$ J. Wróble W ski, op. cit., s. 275; Wojna obronna Polski 1939. Wybór źródet, red. E. KozŁowSKI, Warszawa 1968, s. 729. 
Wyszliśmy z miejskich zabudowań i opłotków. Mszczonów został za nami, ale utkwił głęboko w pamięci. Doszliśmy do rozwidlenia dróg: szosa w lewo prowadziła do Warszawy, zaś prawe rozwidlenie to polna droga. Tą droga poszły nasze oddziały. W dali rysowały się kontury dużego kompleksu leśnego ${ }^{61}$.

Była to droga prowadząca w kierunku wschodnim w stronę Grzegorzewic i Tarczyna, biegnąca przez niewielkie lasy w rejonie pierwszej z wymienionych miejscowości. Miało to wielkie znaczenie, gdyż wobec panowania lotnictwa niemieckiego w powietrzu, przemieszczanie się za dnia, obarczone było dużym ryzykiem. Opuszczając Mszczonów, polscy żołnierze mieli dobre nastroje, gdyż odniesione rankiem zwycięstwo dodało wiary w możliwość kolejnego zwycięskiego starcia z Niemcami.

Pierwszy postój - konieczny dla uporządkowania pododdziałów oraz odpoczynku po nocnym marszu i walkach o Mszczonów - ppłk W. Wnuk zarządził w rejonie folwarku Gnojna (około 2-3 kilometry na wschód od Mszczonowa), gdzie uporządkowano przemieszane pododdziały. Tu także żołnierze mogli nieco odpocząć po męczącym nocnym marszu i porannej walce. Oto jak ten moment wspominał por. Z. Janiak:

Pułk zatrzymał się w niedużym lasku, położonym około półtora kilometra na wschód od Mszczonowa. W niedługim czasie, po opuszczeniu przez nas miasta, artyleria nieprzyjacielska położyła tam swój niszczycielski ogień. Mszczonów zamienił się w gruzy. Około południa do miasta przyjechało 80 czołgów i 20 samochodów. Siedząc na skraju lasu z kpr. Urbaniakiem, z drżeniem oglądałem ten ruch. Dziwne to, że nasz przeciwnik nie rozpoznał na boki, bo z pewnością wykryłby nas w tym lasku. Byłby krwawy bój. Prawdopodobnie nie przypuszczali, że jesteśmy na tyle bezczelni i siedzimy tak blisko ruchliwej drogi ${ }^{62}$.

Jednak przebywanie pułku w pobliżu Mszczonowa stawało się niebezpieczne, toteż około południa ppłk W. Wnuk zarządził jego przegrupowanie do lasów w rejonie Grzegorzewic (około 8 km na wschód od Mszczonowa). Tu spodziewał się przybycia oddziałów 30 DP gen. bryg. L. Cehaka ${ }^{63}$, lecz zamiast tego żołnierze wysłani na rozpoznanie donieśli o ponownym zajęciu Mszczonowa przez

${ }^{61}$ ZKRPWP w Łodzi, sygn. 740, S. Świerczyński, Wspomnienia dziatonowego..., k. 7.

${ }^{62}$ Wrześniowe wspomnienia porucznika..., s. 107.

${ }^{63}$ Wieczorem 11 września gen. bryg. W. Thommée poinformował dowódcę 30 DP, iż zamierzony marsz na Warszawę przez Mszczonów jest już nieaktualny i nakazał dywizji skierować się w kierunku stolicy poprzez Żyrardów. 
oddziały niemieckiego XVI Korpusu Armijnego. Wówczas dowódca 31 pSK miał podjąć decyzję o ostrzelaniu miasteczka ogniem kilku dział, co budzi jednak wśród historyków wątpliwości ${ }^{64}$. Niebawem ppłk. W. Wnukowi doniesiono o pojawieniu się podjazdów niemieckiej $31 \mathrm{DP}$ z kierunku Tarczyna i Piaseczna. W związku z tym dalsze przebywanie w tej okolicy groziło rozbiciem pułku, wobec czego jego pododdziały opuściły w godzinach wieczornych rejon Grzegorzewic i skierowały się w kierunku kompleksu leśnego położonego na południe od miejscowości Łoś (około 8 km na wschód od zajętego już przez Niemców Tarczyna) $)^{65}$. Dalsza epopeja wojenna 31 pSK wykracza już poza ramy tematyczne niniejszego artykułu. Warto jednak zasygnalizować, iż osłabione pododdziały pułku dotarły 12 września do lasów w rejonie miejscowości Łoś (na wschód od drogi Grójec-Warszawa). Gdy okazało się, że dalszy odwrót w kierunku Wisły jest niemożliwy, ppłk W. Wnuk nakazał pułkowi marsz w kierunku południowym ku Pilicy. Po przekroczeniu nocą z 13 na 14 września tej rzeki, podjął on przegrupowanie w kierunku Puszczy Kozienickiej, gdzie został okrążony i 18 września zmuszony do kapitulacji ${ }^{66}$.

Po odzyskaniu przez Niemców Mszczonowa na jego mieszkańców spadty krwawe represje. W odwecie za pomoc udzieloną polskim żołnierzom, rankiem 11 września rozstrzelano bez sądu przy murze kościelnym burmistrza Aleksandra Tańskiego, lekarza dr. Stanisława Zarachowicza i proboszcza tutejszej parafii - księdza Jerzego Wierzejskiego, przy plebani zaś zastrzelono także wikariusza parafii - księdza Władysława Gołędowskiego (dwa dni później zostali oni pochowani we wspólnej mogile na kościelnym cmentarzu). Po egzekucji, mieszkańców miasteczka spędzono do kościoła, gdzie ich zamknięto, natomiast ludność żydowską wypędzono z miasteczka. Następnie Niemcy podpalili zabudowania przy obu rynkach oraz przy głównych ulicach (Rawskiej i Warszawskiej), które do tej pory ocalały z wojennej zawieruchy (spłonęły wówczas m.in. synagoga oraz stare księgi parafialne, znajdujące się na plebanii kościoła). Mszczonów przestał praktycznie istnieć, lecz nie załamało to jego mieszkańców, którzy od 12 września zaczęli mozolnie odbudowywać swe domy. Wiedzieli, że okupacja niemiecka

${ }^{64}$ M. Bielski, op. cit., s. 240. Brak potwierdzenia informacji o rzekomym ostrzelaniu Mszczonowa u J. Wróblewskiego (op. cit., s. 275), jest ona natomiast w PSZ (t. 1, cz. 3, s. 187), powtórzona przez M. Bielskiego i P. Zarzyckiego (op. cit., s. 33).

65 PSZ, t. 1, cz. 3, s. 187-190; J. WróbleWSKi, op. cit., s. 275.

66 Vide: W. Jarno, W. KozŁowski, op. cit., s. 236-250; W. Jarno, Strzelcy Kaniowscy..., s. 300-306. 
będzie dla nich trudnym czasem, lecz zapewne nie przypuszczali (podobnie jak większość Polaków), że będzie trwała niemal pięć lat ${ }^{67}$.

Na zakończenie warto dodać, iż zdobycie Mszczonowa przez żołnierzy 31 pSK rankiem 11 września miało poważne reperkusje. Dowództwo niemieckie, nie znając precyzyjnie sił polskich biorących udział w tej akcji, obawiało się, że uderzenie wspomnianego pułku może być częścią większej polskiej operacji zaczepnej i musiało zrezygnować z forsowania Wisły przez 1 DPanc. i 31 DP, zawracając część jej oddziałów w kierunku Mszczonowa. Dopiero po ponownym zajęciu tego miasteczka i nie stwierdzeniu w godzinach popołudniowych 11 września w jego pobliżu większych sił polskich, dowództwo niemieckie doszło do przekonania, że w rejonie tym nie przebywało żadne większe polskie zgrupowanie, jak podejrzewano jeszcze w godzinach porannych. W konsekwencji, dopiero w godzinach popoludniowych wstrzymano dalsze przegrupowania jednostek w kierunku Mszczonowa. Opóźniło to jednak o jeden dzień ich marsz ku Wiśle, przez co sukces taktyczny 31 pSK nabrał większego wymiaru, hamującego - co prawda na krótko - wyścig nieprzyjaciela ku wspomnianej rzece.

\section{BIBLIOGRAFIA}

\section{Źródła archiwalne}

\section{Centralne Archiwum Wojskowe, Wojskowe Biuro Historyczne w Warszawie}

Kampania wrześniowa, sygn. II.2.219 i II.3.13 oraz akta personalne Wincentego Wnuka, sygn. 4849, 742.61.2048 i I.482.69-6130.

Związek Kombatantów Rzeczypospolitej Polskiej i byłych Więźniów Politycznych

Zarząd Okręgowy w Łodzi, sygn. 648, 740 i 782.

${ }^{67}$ „Merkuriusz Mszczonowski” 2007, nr 8 (130), s. 7 i 9; [b.a.], Mszczonów (relacja swiadka)..., s. 2. 


\section{Źródła drukowane}

Kpt. A. Ogrodnik, Relacja z okresu Kampanii Wrześniowej 1939 r. 31 putku Strzelców Kaniowskich, oprac. A. Ruszkowski, „Na Sieradzkich Szlakach” 2009, nr 3 (95), s. 13-16.

Wojna obronna Polski 1939. Wybór źródet, red. E. Kozłowski, Warszawa 1968.

\section{Pamiętniki i wspomnienia}

Adamski W., Kampania wrześniowa 193931 putku Strzelców Kaniowskich w relacjach ofcerów 31 pSK, Kozienice 2009.

Gicgier T., Wojenne drogi, „Odgłosy” 1979, nr 35, s. 11.

Malanowicz A., Opowieść o konającym żotnierzu, „Za Wolność i Lud” 1980, nr 44, s. 11.

Mszczonów (relacja świadka), „Żołnierz Polski w Kampanii Wrześniowej” 1941, nr 31, s. 1-2 (dodatek do „Wiadomości Polskich” 1941, nr 31).

Rómmel J., Za honor i Ojczyznę. Wspomnienia dowódcy armii „Łódż” i „Warszawa”, Warszawa 1958.

Rżewski A.S., Pamiętnik jeńca, Łódź 1986.

Thommée W., Oni uratowali honor Armii „Łódż”, „Wrocławski Tygodnik Katolików” 1961, nr 2, s. $4-5$.

Wrześniowe wspomnienia porucznika Zenona Janiaka. Pamiętnik dowódcy 7. kompanii strzeleckiej 31 putku Strzelców Kaniowskich z Września 1939 roku, red. i oprac. B. Rosiński, M. Bednarek, K. Zając, Łódź-Kozienice 2018.

\section{Opracowania}

Artyleria konna w kampanii wrześniowej 1939 roku. Książka pamiątkowa, oprac. J. Boguski, Londyn 1976.

Bielski M., Grupa Operacyjna „Piotrków” 1939, Warszawa 1991.

Dymecki P., Bitwa mszczonowska 31 Putku Strzelców Kaniowskich, „Merkuriusz Mszczonowski" 2008, nr 9, s. 15-19.

Emmerling M., Luftwaffe nad Polska 1939, cz. 1:Jagdflieger, Gdynia 2002; cz. 2: Kampfflieger, Gdynia 2005, cz. 3: Stukaflieger, Gdynia 2006.

Galster K. L., Ksiega pamiatkowa artylerii polskiej 1914-1939, Londyn 1975.

Głowacki L., Obrona Warszawy i Modlina na tle kampanii wrześniowej 1939 r., Warszawa 1985. 
Jarno W., Strzelcy Kaniowscy w latach 1919-1939, Warszawa 2004.

Jarno W., Kozłowski W., 10 Dywizja Piechoty w wojnie 1939 roku, Pruszków 2016.

Kawalerowie Virtuti Militari 1792-1945, t. 3: 1939, cz. 1, Koszalin 1997.

Kozłowski W., Ptk Wincenty Wnuk (1897-1987), żotnierz i dowódca września 1939 r. Szkic biograficzny, [w:] Si vis pacem, para bellum. Bezpieczeństwo i polityka Polski. Ksiega jubileuszowa ofiarowana profesorowi Tadeuszowi Dubickiemu, red. R. Majzner, Częstochowa-W łocławek 2013, s. 803-822.

Kukuła P.A., Maszeruja strzelcy, Łódź 1972.

Łukomski G., Polak B., Suchcitz A., Kawalerowie Virtuti Militari 1792-1945. Wykazy odznaczonych za czyny z lat 1863-1864, 1914-1945, Koszalin 1997.

Łukomski G., Polak B., Suchcitz A., Kawalerowie Virtuti Militari 1792-1945, t. 3: 1939, cz. 1, Koszalin 1997.

Order Virtuti Militari, red. K. Filipow, G. Jasiński, Warszawa 2013.

Polskie Sity Zbrojne w II wojnieśsiatowej, t. 1: Kampania wrześniowa, cz. 3: Przebieg dziatań od 9 do 14 września, Londyn 1959.

Porwit M., Komentarze do historii polskich dziatań obronnych 1939 roku, cz. 2: Odwrót i kontrofensywa, Warszawa 1983.

Wesołowski A., Podputkownik Wnuk i jego żotnierze, [w:] Żotnierze Września 1939, red. K. Sikora, A. Wesołowski, Warszawa 2012, s. 326-330.

Wróblewski J., Armia „Łódż” 1939, Warszawa 1975.

Zarzycki P., 10 Kaniowski Putk Artylerii Lekkiej, Pruszków 1997.

Zawilski A., Bitwy polskiego Września, Warszawa 1972, t. 2, Warszawa 1989.

\section{Netografia}

Dymecki P., Mszczonowski wrzesień 1939, https://www.mszczonow.pl/249,mszczonowski-wrzesien-1939? tresc $=273$ (dostęp: 22 VIII 2020).

\section{Witold Jarno}

\section{BATTLE OF MSZCZONÓW IN SEPTEMBER 1939}

Summary. The article describes the capture of Mszczonów by soldiers of the 31st Kaniowski Rifle Regiment on 11 September 1939. At that time, the regiment fought in isolation from its own 10th Infantry Division and retreated independently towards the Vistula. The battle fought by the regiment was one of the greatest successes of its soldiers during the September campaign of 1939, although for many years it remained in the shadow of the parallel battle on the Bzura River. Only in recent years the memory of this somewhat forgotten victory has begun 
to be restored. The capture of Mszczonów by the units of the 31st Kaniowski Rifle Regiment brought glory to the regiment. His actions led, albeit for a short time, to panic in the command of the German XVI Army Corps, which was not aware of the forces that took part in the fight. The soldiers of Lieutenant Colonel Wincenty Wnuk achieved a tactical success which - although it did not bring any operational benefits - nevertheless raised the declining morale. It should be emphasized that for this victory the regiment was awarded the Virtuti Militari V class in 1966.

Keywords: Polish-German war in 1939, Mszczonów, Lieutenant Colonel Wincenty Wnuk, 31 Infantry Regiment 